Article

\title{
Fictional Crimes/Historical Crimes: Genre and Character in Philip Kerr's Berlin Noir Trilogy
}

\author{
Laura Major ${ }^{1,2}$ (D) \\ 1 English Department, Achva Academic College, Arugot 7980400, Israel; drlauram@gmail.com \\ 2 English Department, Hemdat Hadarom College, Sdot Negev 85151, Israel
}

Received: 12 September 2019; Accepted: 12 November 2019; Published: 14 November 2019

\begin{abstract}
This paper will explore Philip Kerr's Berlin Noir trilogy, composed of March Violets (1989), The Pale Criminal (1990), and A German Requiem (1991), discussing the overlap and blurring of generic boundaries in these novels and the ability of this form to reckon with the Holocaust. These detective stories are not directly about the Holocaust, and although the crimes investigated by the mordant Bernie Gunther are fictional, they are interweaved with the greater crimes committed daily by the Nazi Party. The novels are brutally realistic, violent, bleak, and harsh, in a narrative style highly appropriate for crime novels set in Nazi Germany. Indeed, with our knowledge of the enormity of the Nazi crimes, the violence in the novels seems not gratuitous but reflective of the era. Bernie Gunther himself, who is both hard-boiled protagonist and narrator, is a deeply flawed human, even an anti-hero, but in Berlin, which is "alive" as a character in these novels, his insights, cloaked in irony and sarcasm, highlight the struggle to resist, even passively, even just inside one's own mind, the current of Nazism. Although many representations of the Holocaust in popular fiction strive towards the "feel good" story within the story, Kerr's morally and generically ambiguous novels never give in to this urge, and the solution of the crime is never redemptive. The darkness of these novels, paired with the popularity of crime fiction, make for a significant vehicle for representing the milieu in which the Holocaust was able to occur.
\end{abstract}

Keywords: Holocaust; crime fiction; hard-boiled; noir

\section{Introduction}

Debates regarding the legitimacy and appropriateness of literary forms to represent the Holocaust have raged for decades, from Adorno's famous characterization of poetic production post-Auschwitz as "barbaric," to Vice's proclamation that "writing Holocaust fictions is tantamount to making a fiction of the Holocaust" (Vice 2000). Notwithstanding the academic disputes regarding Holocaust representation, the various genres dealing with the Holocaust, especially the popular, have grown and thrived in the decades since the events transpired.

Crime fiction is one of these popular forms, and Philip Kerr's Berlin Noir trilogy featuring detective Bernie Gunther is a meaningful platform on which to test the question of popular crime fiction as a vehicle for Holocaust representation. This article attempts to show how the blending of crime novel sub-genres in the Bernie Gunther series-hardboiled, urban noir, historical crime fiction, and even the form of crime fiction where the protagonist is a criminal-probes the limits of the genre in representing the historical trauma of the Holocaust. This overlap between genres, together with a subtle undermining of the genre by making intertextual allusions, employing the tropes of irony and metaphor, and flouting the redemptive plot common in crime fiction, enable an escape from the formulaic and a reckoning with the representation of the Holocaust in this genre.

No matter with which side of the polemic regarding fictional representation of the Holocaust one identifies, the pragmatic approach of Laurence Langer provides a way to discuss popular Holocaust 
fiction without having to locate oneself on the continuum between perceiving the Holocaust as unknowable and unrepresentable ${ }^{1}$ and seeing any form of Holocaust representation as adequate to the task and legitimate. Langer rather laconically notes that "since a vast body of Holocaust literature already exists, the issue of whether it 'should' or 'can' be written is pointless" (Langer 1995). For Langer, the relevant question "is how words help us imagine what reason rejects." Langer, it must be acknowledged, anthologizes Holocaust literature of "artistic quality" (Langer 1995) and "intellectual rigor" (Langer 1995), but his remark about words and reason can be applied to popular forms too. Yet, because popular literature tends to be less concerned with the aesthetics of language, Adorno's concerns about Holocaust representation, "to squeeze aesthetic pleasure out of artistic representation of the naked bodily pain of those who have been knocked down by rifle butts" (Adorno 1986), become secondary to the problems of cheapening, commercializing, white-washing, and even misrepresenting the Holocaust, problems that accompany popular genre fiction, especially those that offer redemptive formulas at their conclusion.

Reading crime fiction is pleasurable, and the pleasure is generated by the binary nature of this genre, its voyeuristic qualities, and the return of order and justice at the novel's conclusion. Indeed, crime fiction provides the reader, in most cases, with the eventual relief of good prevailing over evil. Crime fiction also places the reader in a position of solving puzzles and mysteries, certainly a comforting and empowering experience given the uncertainty of reality and everyday life. The voyeuristic aspects involve peeping and prying into the lives and minds of victims, criminals, and detectives. By creating a fictional situation that necessitates detection, readers are relieved of any guilt accompanying the voyeurism (Rzepka and Horsley 2010). The guiltless pleasure readers experience as they unravel mysteries and vicariously, but safely from the comfort of their homes, of crime and violence, accompanied and mitigated by the ultimate comfort and catharsis afforded by the triumph of justice, might seem benign enough when discussing entertainment and escapism. When, however, this genre grapples with historical trauma, ethical questions regarding the propriety of pleasure-inducing reading come to the fore. Donahue, who critically analyzes Bernhard Schlink's detective novels, scathingly asks in this vein "how the topics of Nazism and the Holocaust lend themselves to such great fun" (Donahue 2004). Aarons argues that narratives that are committed to "responsible representation" (Aarons 2014) of the Holocaust should not only avoid producing pleasure in the reader, but instead should "create the conditions for discomfort and unease" (2014). This article will show how Kerr in Berlin Noir walks the tightrope between the demands of popular fiction and the demands of ethical representation.

Crime fiction has flourished in popular culture; in the United Kingdom, for example, in 2017, crime fiction outsold all other genres combined. In the ivory tower, conversely, scholars have been long divided regarding the literary value of the genre. W.H. Auden, who was a self-proclaimed "addict" of detective fiction, once said, "the interest in the detective story is the dialectic of innocence and guilt" (Auden 1948). Focusing on the redemptive plot, Auden explains how readers experience a "magical satisfaction" when social order triumphs over the chaos of crime (Auden 1948). In his 1936 poem "Detective Story," Auden (Auden and MacNeice [1936] 2018) repeats the line "all goes to plan", emphasizing the formulaic structure of crime fiction, whereas in his essay "The Guilty Vicarage", he points at the binaries and at the pleasure in the redemptive plot, going so far as to trace the reader's "phantasy" as "being restored to the Garden of Eden" (Auden 1948), to a pure and innocent state. Unlike Auden, Edmund Wilson decried the genre as "a field which is mostly on a sub-literary level" (Wilson 1945), and more recently Donahue called it "truly Teflon (2004)" and "pure entertainment with no obligation to instruct, ennoble, edify, disrupt, subvert, or-least of all, defy commodification"

1 Claude Lanzmann, producer of the documentary Shoah, says, for example, that "there are things that cannot and should not be represented" (Lanzmann 1994). Eli Wiesel, too, insists that "the Holocaust cannot be described, it cannot be communicated, it is unexplainable" (Reichek 1976). In this camp, concerns persist about appropriation, sanitization, and the side-lining of survivor testimony. Hartman warns, "In the light of media over-exposure, the evil of the Holocaust becomes strangely weightless" (Hartman 1994). 
(Donahue 2004). Although perhaps ennobling is too a lofty aspiration for crime fiction, we will see how crime novels, and Kerr's novels in particular, disrupt and subvert the genre to make the reader's encounter with the realities of Nazi Germany unsettling and provocative.

When crime fiction meets the Holocaust, the question of the appropriateness and ability of this genre to deal with Holocaust themes cannot be avoided. Diemert, for example, asks, "is it possible for an essentially formulaic structure to bear the weight of history and, particularly, the liminal event of historical trauma (Diemert 2002)?" In other words, how can genre fiction, with its formulas and conventions, and particularly the redemptive plot, adequately and faithfully represent an event that defies comprehension in its extremity, one that ruptured historical convention and devastated humanity? Donahue insists that crime fiction is inappropriate for the task, explaining that the genre of detective fiction mystifies Nazism by making it "the great unknown foundational crime" (Donahue 2004) and thus redirects the reader's attention to lesser and solvable crimes. Certainly, crime fiction dealing with Nazism, Berlin Noir included, must grapple with the place and prominence of the large-scale crime within the narrative of the small-scale crime.

Kerr's Berlin Noir trilogy spans the pre- and post-World War II periods but skips over the actual war years, in itself perhaps a sort of escape from the time and arena in which the Nazis committed their gravest crimes. When we meet Bernie Gunther in the first book in the trilogy, March Violets (Kerr 1989), set in 1936, he is a private investigator who once worked for the Berlin police, Kripo (Kriminalpolizei). In the second book, The Pale Criminal (Kerr 1990), set in 1938, he has joined Kripo once again (not by choice), whereas in the third novel, A German Requiem (Kerr 1991), set in 1947, he returns to private investigation, but on the surface is in the employ of a Soviet officer. ${ }^{2}$

\section{From the Vicarage to the Real World: Sub-Genres of Crime Fiction}

Carl Malmgren divides crime narratives into three main sub-genres: mystery fiction, typified by Agatha Christie-like novels; detective fiction, the category to which the Gunther novels ostensibly belong; and crime fiction. Malmgren uses Raymond Chandler's denunciation of mystery fiction as being "hopelessly outdated", inauthentic, and unrealistic, "living psychologically in the age of the hooped skirt" (Chandler 1972), to highlight the uniqueness of detective fiction, and particularly the hard-boiled type (Malmgren 1997). Chandler is of course the creator of Philip Marlowe, an archetype of the straight-shooting, rough talking, sometimes dysfunctional and alcoholic hard-boiled detective, to whom Kerr's Bernie Gunther bears a strong literary resemblance.

According to Malmgren, who adopts Chandler's view, detective fiction was born by breaking with the conventions of mystery fiction. It depicts a real world, "a decentered world" (1997), which "undermines mystery's basic predicates: order, stability, necessity, causality, and resolution" (1997). In detective fiction, the whole truth is not disclosed; in fact, the notions of "Truth, Justice, and Resolution" (1997) are destabilized, and replacing these is the individuality of the detective. Detective fiction, says Grella is "more preoccupied with the character of its hero, the society he investigates, and the adventures he encounters, than with the central mystery, which gets pushed aside by individual scenes and situations" (Grella 1980), and thus, as readers, we are invested in the character and actions of the detective. Also, this hard-boiled detective is a fallible and flawed being, an anti-hero, whose actions sometimes make him "part of the problem" (Most 1983). Usually, the detective overcomes the temptations of darkness, but, given his milieu, he sometimes succumbs to nefarious forces. When this happens, the narrative turns into crime fiction, where the protagonist is the criminal. Detective fiction offers "the integrity of the investigator ... as compensation for a the "the squalid world he

2 Kripo, to provide historical context, was combined with the Gestapo in 1936, by SS head Heinrich Himmler, who became German chief of police. The Gestapo and Kripo came to form the security police (Sicherheitspolizei) under SS Lieutenant General Richard Heydrich, whereby essentially Gestapo and Kripo officials became SS officers, and the police and SS were merged so that the SS would dominate and control policing of the state (Hall 2013). 
or she inhabits" (Malmgren 1997), whereas in crime fiction that self is eroded, as are notions of essential goodness.

\section{Hard-Boiled or Crime Fiction? Detective or Criminal?}

At times, the Bernie Gunther novels slip from the hard-boiled detective novels defined above to crime fiction, described by Malmgren as inhabiting the perspective of the criminal. The novels can also be said to share characteristics with the historical crime novel and the urban noir genre, to be described below. This overlap or blurring between genres is, according to Berel Lang, common in genres dealing with Holocaust, representing, in Lang's words, "a subversive relation to the conventions of literary genre" (Lang 2000). Lang states further "that the challenge to these conventions is itself a representational element in the works in which it appears" in that the genres act "in the role of moral and historical as well as aesthetic representation" (Lang 2000). Holocaust writing, argues Lang, can "push certain features of writing to their limits, in some cases to their destruction" (Lang 2000). The inability of genres to contain the enormity of the Holocaust poses a representational challenge to any genre and causes the genre to overspill its generic borders. The resulting breakdown of generic borders is itself a commentary on the inadequacy of language and forms to contain the subject of the Holocaust. The destruction mentioned by Lang seems to describe a case where the genre is no longer identifiable. Though in the Bernie Gunther series the greater genre of crime fiction is certainly recognizable, its subgenre is much less so.

Thus, though Gunther is a hard-boiled detective, he is also, in Katharina Hall's view, a "Nazi detective" (Hall 2013). This shift of the Nazi "from his customary position of "murderer" to detective" ... creates, according to Hall, "a highly complex investigative agent" (Hall 2013) - "His role within the fascist apparatus engenders a fundamental tension between the two primary components of the Nazi detective: the investigator who is presumed to seek truth and justice and the Nazi who represents a criminal regime" (2013). Even if one disagrees with Hall's identification of Gunther as a Nazi, readers cannot ignore his membership in Kripo (past and present), which de facto classifies him as a Nazi officer, his missions executed at the bidding of Nazi criminals, Goering, Nebe, Himmler, and Heydrich, or his (albeit passive) participation in mass executions in Mintz. In A German Requiem, he elucidates in an uncharacteristically neutral tone on the extent of his involvement,

My own duties at the Group's Minsk headquarters had involved the seizure of the records of the Russian NKVD [People's Commissariat of Internal Affairs] and the capture of an NKVD death-squad ... it soon became apparent to me that ... the primary purpose of the Action Groups was ... the systematic murder of Jewish civilians ... Although I was not personally charged with the task of commanding any of these mass-execution squads, I reasoned that it could only be a matter of time before I was so ordered, and as an inevitable corollary, before I was shot for refusing to obey. So I requested an immediate transfer ... . (Kerr 1991)

Hall points out the conundrum of the writer representing the "Nazi detective" - he can be presented "as a noble exception", acting with honor despite the pervading criminality. This strategy may, however, "draw a charge of distorted historical representation or revisionism" (Hall 2013). However, if the writer allows for too much of the detective's Nazi identity to shine through, they risk dashing "the reader's expectation of a fundamentally decent detective" (2013) and thus "generating a textual crisis" (2013) where the reader cannot identify with the detective. Thus, writers, and Kerr among them, have their detectives walk this tightrope in relation to the state, thus "exploring the scope of his moral agency and/or corruption" (Hall 2013). How do they resist and when do they succumb? Gunther, as we see above, is certain he would have refused to obey orders, but mentioning the threat on his own life that would ensue from not obeying might be seen as qualifying the amount of agency given to those operating in the Nazi order, and in some measure allowing for the "just following orders for fear of my life" argument. 
The delicate dance performed by the detective in the Nazi state enables the reader to ask these questions and explore the workings of the police state. How much agency are people granted in such a state, and what choices do they have? Gunther indeed frames his dilemma in Mintz as the choice between killing and being killed, and his other missions at the beck and call of Nazi leaders as choices that leave no choice. Langer discusses the notion of "choiceless choice" (Langer 1980) or the impossibility and obliteration of moral choice in the very particular context of the extermination and concentration camps, and much of his argument rests on the reality created in Aushwitz, "a situation beyond good and evil that even a Nietzsche could not imagine" (Langer 1980). We can, however, apply to Gunther's framing of his dilemma Langer's point that the Nazi regime created conditions in which "humanly significant alternatives-that is, alternatives enabling an individual to make a decision, act on it, and accept the consequences, all within a framework that supports personal integrity and self-esteem" were absent, thus plunging one "into a moral turmoil that may silence judgment ... but cannot paralyze all action, if one still wishes to remain alive" (Langer 1980). Gunther does not conceal or mispresent his culpability, and this honesty and self-reflection allows the reader to identify with him. He attempts to be candid about his precarious position, and admits that because Arthur Nebe ${ }^{3}$ approved his transfer from Minsk to the War Crimes Bureau, "it always gave me a strange kind of feeling to know that I very possibly owed my life to a mass murderer" (Kerr 1991).

Gunther thus occupies a morally ambiguous space between hard-boiled detective, who is redeemable, and Nazi complicit rogue, who is not. Although he moves between outsider and insider status, he never identifies with the Nazi ideology and its representatives, which he despises and derides. However, he sometimes raises doubts in the reader regarding his insider/outsider status. In The Pale Criminal, for example, Gunther describes the first time he says the words "Heil Hitler" "not out of obligation, in response to someone else, in which situation I might have consoled myself with the excuse that I was just keeping my head down and avoiding the trouble of giving offence" (Kerr 1990). At this moment he realizes "that the only real complaint I had at the Alex [the police headquarters on the Alexanderplatz] was going to be against myself" (Kerr 1990). Later, in the same novel, Gunther rather wretchedly describes his moral position, "I'm no knight in shining armour. Just a weather-beaten man in a crumpled overcoat on a street corner with only a grey idea of something you might as well go ahead and call Morality" (Kerr 1990). He admits to being unscrupulous with money and recognizes his lack of good works, but "I was through looking at my fingernails when there were thieves in the store" (Kerr 1990). He is tired of keeping a low profile and closing his eyes to the cruel realities around him, and readers are convinced here that Gunther is going to act on the very disturbing information he has uncovered in his investigation of the deaths of seven young German girls.

\section{Irony and Metaphor: Tools of (Private) Resistance and Disruption}

To somehow retain outsider status, independence of thought and thus partial redemption as a detective and person, Gunther must somehow defy the Nazis, even if only in his mind, as to do so too blatantly is to invite serious recrimination. Thus, in the sardonic, wise-cracking fashion of the hard-boiled detective, Gunther resists the Nazis in ironic thought and speech. Lake discusses this use of irony in depth, and, drawing on Arendt's terms, maintains that one who acts "normal" in Nazi Germany "is a person who resists the new abnormal norms of Nazi society" (Lake 2016). On one level, Gunther does this by ironically mocking the Nazis. For example, when pompously told to "never underestimate luck", Gunther thinks "just look at the Fuhrer" (Kerr 1989). He refers to Goebbels as "Joey" and remarks on the "finishing school manners" (Kerr 1990) of the Gestapo. To Gunther, Mein Kampf is "that funny old book they give free to all newlyweds" (Kerr 1990) and thus "the best reason to stay single". One of the only perks of his job, he reports, "was the opportunity it afforded to piss on the

3 Arthur Nebe, who stood at the helm of Kripo from 1933 to 1945, was both a Gestapo official and SS major general. He commanded the Einsatzgruppe B (Action Group B) for five months in 1941, executing 46,000 murders in the Minsk area (Hall). 
Gestapo's shoes" (Kerr 1990). However, he also employs his ironic tone to deal with the realities of the Holocaust, and this use of irony is far more fraught. According to Lake, an ironic view is the only way for Gunther, who struggles to hold onto his personal moral code, to make sense of the highly abnormal and absurd situations caused by the juxtaposition of large-scale and small-scale crime (Lake 2016).

Gunther's ironic and resisting lexicon also includes abundant use of animal imagery throughout the trilogy, most often used in describing Nazis. In describing Nazis as animals, and never in a flattering manner, Gunther is reversing the Nazi manner of using animal imagery to dehumanize and disparage Jews and other persecuted populations. However, Kerr is also using metaphor as a strategy for, in Aarons' words, "shaping and extending, in a textually material sense, the experience of response to trauma" (2014). ${ }^{4}$ Metaphor, "a transformative disturbance of renaming or reconfiguring" (Aarons 2014), in addition to other figures of speech enumerated by Aarons, is a trope that writers draw upon to "cause disruption and unease" (2014). Thus, a Nazi edges towards him "like a crab with a bad case of corns" (Kerr 1989) and is later described as a weasel with a "hungry-cat stare" (Kerr 1989). Police offices are referred to as bulls, and Goering's lackey as a "bloodhound" (Kerr 1989); Goering himself reminds Gunther of a "big, fat, man-eating tiger" (Kerr 1989). Heydrich smiles like a "guilty dog" (Kerr 1990), and Arthur Nebe has an "old fox's face" (Kerr 1991). Nebe's violent Latvian emissary looks like a "circus horse" (Kerr 1991), is "loyal as a dog" (Kerr 1991), but who attacks like a "savage tiger" (Kerr 1991). ${ }^{5}$ This trope, repeated through the trilogy, unsettles and destabilizes the reader in "moments of disequilibrium" (Aarons 2014), drawing attention to the extremity of the historical events.

In contrast to the pervasive animal imagery, when describing Jesse Owens' running the infamous 1936 Berlin Olympiad, Gunther pronounces a description of Owens as a gazelle as inaccurate, "Watching the tall, graceful negro accelerate down the track, making a mockery of crackpot theories of Aryan superiority, I thought that Owens was nothing so much as a Man, for whom other men were simply a painful embarrassment" (1989). Owens, derided as racially inferior by Nazi ideology, is declared a man, whereas the Nazis are animals in the sense of lacking humanity and a moral code and behaving in a predatory and beastly fashion.

\section{Historical Crime Novel and Urban Noir}

Added to the mix, overlap, or in Lang's term, "blurring" of hard-boiled detective novel and crime novel sub genres discussed above is historical crime novel, which combines history with crime fiction, setting the crime in a larger historical context. In the case of Berlin Noir, the physical setting of Berlin, spanning the end of the Weimar Republic to almost the beginning of World War II in March Violets and The Pale Criminal, respectively, and the aftermath of the war in A German Requiem, plays a central role in the novel, serving as much more than mere backdrop. In fact, by drawing attention to the noir aspect in the trilogy title in relation to Berlin, Kerr places his historical crime fiction also in the genre of urban noir. Noir, of course, refers not only to the hard-boiled form with which it overlaps, but also to the dark, sinister mood and themes—politically, socially, and psychologically—that prevail in the novel. ${ }^{6}$ Although the city is central in all hard-boiled novels, Gunther's Berlin becomes a character, the embodiment of an urban dystopia, which forces the reader to confront the dangers and oncoming catastrophe of World War II and its disastrous aftermath. Historical accuracy and rich details of a Berlin peopled with Nazi characters we know from history books transport the reader to this disturbing milieu, with the retrospective of history amplifying our discomfort while reading. This discomfort is an essential part of the reading experience, preventing the reader from really enjoying the books and

4 Art Spiegelman's 1986 graphical novel MAUS takes the animal metaphor even further, completely throwing the reader into an unfamiliar and uncomfortable reading experience.

5 Significantly, The Zoo Station features prominently in The Pale Criminal, in which Gunther actually visits the zoo.

6 It can also be argued that with his Berlin Noir trilogy Kerr initiated a sub-genre of mystery writing called Berlin Noir, with authors such as Jonathan Rabb, Jeffery Deaver, David Downing, David John, Rebecca Cantree, Joseph Kanon, and others setting their novels in a dark Berlin. 
from feeling the relief that the solution of crime is supposed to bring. Instead, the reader "walks" the streets of Berlin in the text, "breathes in" its oppressive air, and is drawn into the noir of the setting.

In March Violets, Gunther describes the change in Berlin from its Weimer days to its National Socialist days, "I used to love this old city, but that was before it had caught sight of its own reflection and taken to wearing corsets laced so tight it could hardly breathe" (Kerr 1989). A few lines later he moves from personification to metaphor, comparing Berlin to "a big haunted house with dark corners, gloomy staircases, sinister cellars, licked rooms, and a whole attic of poltergeists on the loose" (Kerr 1989). He describes the forced broadcast of Goebel's propaganda speeches, the forced salutes to the Brownshirt legions, the incongruity of the Olympic games with the athletic performance of African American Jesse Owens, and the queues of Jews applying for exit visas. In this Berlin "the air tastes like pencil shavings" (Kerr 1989) and what was once beautiful countryside is now "a torn, brown valley" (Kerr 1989).

In The Pale Criminal, Berlin of 1938 is painted as outdated, absurd, and pretentious, in addition to being on the brink of ruin, "Its façade blackened by smoke, the Reichstag looked like a volcano which had seen its last and most spectacular eruption" (Kerr 1990). Describing Berliners, Gunther quips "tourists think that a lot of Berlin men like dressing-up as women, but that's just the ugly women giving the men a bad name" (Kerr 1990). The architecture is described in great detail with words like "monolithic", "almost Byzantine", "Gothic folly", "florid", "renaissance style", "relic-ornamented", "palladian", "a wedding cake of a house", "Neo Gothic", and "grand" (Kerr 1990), suggesting a city stuck in a ridiculous sense of its own importance. According to Gunther, "they built them big just to remind you of the importance of the state and the comparative insignificance of the individual" (Kerr 1990), so that the physical city serves as a metaphor for the running of the state. Side by side these ostentatious buildings are descriptions of "dirty brown", "dilapidated", "chaotic" buildings, streets, and scenes. This juxtaposition of the ridiculously palatial and the decrepit parallels the gap between the Nazis and those categories of people destined for extermination. The Pale Criminal ends with a description of the aftermath of the infamous Kristallnacht, the night of shattered glass. Gunther describes a synagogue as a "gutted ruin of charred beams and burned-out walls" (Kerr 1990) and the streets covered in glass "like the pieces of a huge, icy jigsaw cast down to the earth in a fit of pique by some ill-tempered prince of crystal" (Kerr 1990). The novel ends with the ominous words, "I could taste the very end of everything" (Kerr 1990), hardly a typical ending in a genre with a supposedly redemptive plot. Indeed, in that gap between The Pale Criminal set in 1938 and A German Requiem set in 1947, the very end of everything, of the world as it existed pre-Holocaust, really did occur.

In A German Requiem, post-war Berlin, described as "ruined by the vanity of men", is held up in comparison to Vienna, where much of the plot, which veers into yet another genrenovel-takes place. Vienna also has its share of ruins, with the "ruined Kunsthistorische" the "ruined museum" and the "large ruined building" (Kerr 1991) but has nothing like the "ruins of an epic scale" in Berlin. Berlin resembles "a colossal Acropolis of fallen masonry and ruined edifice, a vast and unequivocal megalith to the waste of war and the power of 75,000 tons of high explosive" so that the very air is "combusted"; the "ruined Kaiser Wilhelm church", the "old ruined Reichstag", the "bombed out opera house", and the "derelict buildings" all fashion Berlin of 1947 into a city of ashes, part of the "wreckage of Germany". Hunger is everywhere, in Berlin and in Vienna, and the exchange of cigarettes, cash, food, and drink feature heavily in the narrative. Yet, in Vienna Gunther is able to gain some weight, while Berlin is starving, destroyed, a disaster. Gunther's wife tells Bernie of an incident in Berlin where police "found an old couple dining off the raw flesh of a pony they had dragged off the street and killed with rocks" (1991). In this tale, Berlin becomes the scene of a horror story. The city, like a dynamic character in the trilogy, has changed from a tense, coercive place to a pompous destructive beast to a ruined and destroyed shell.

The framing of a crime novel in Nazi Germany adds yet another dimension to the detective story. Kniesche explains that "framing the individual cases of crime (what can be called small scale crime) within the larger context of ... Nazi history inevitable refers to the criminal structures of society itself 
(large scale crimes)" (Kniesche 2013). In March Violets, for example, Gunther is hired by a wealthy steel magnate to find a highly valuable diamond necklace, missing after his daughter and son in law were (presumed) murdered. Readers might reasonably ask what possible importance this crime can have in the context of Nazi Germany, where crimes of an infinitely greater scale were being committed daily. Kerr's answer to this question is in the conclusion of his novel, which refuses to offer redemption. Although Gunther solves the case of the necklace, the novel does not end with order being restored and the triumph of the lone detective. Rather, at the very end of the novel, Gunther is sent to Dachau by Heydrich to tie up a loose end of the case, and there he is faced with the what he calls "something that made you mute with horror" (Kerr 1989). Witnessing the terrible conditions, cruelty and death in Dachau of 1936 (which, of course, cannot even be compared to the death camps operating the 1940s) silences the gregarious Gunther into "a silence born of shame" (Kerr 1989) and causes him to face the moral necrosis of the Fatherland (Kerr 1989). What meaning can solving the case of the industrialist's daughter and the missing necklace possibly have in the context of Dachau? That the novel more or less ends with Gunther's experience in Dachau, throws the small-scale crime into complete irrelevance against the crimes against humanity being perpetrated in Nazi Germany.

Gunther is also powerless and quiet in the face of the large-scale crime. He ends the novel by lamenting how he has grown used to "living in a world that is out of joint, as if it has been struck by an enormous earthquake so that the roads are no longer flat, nor the buildings straight" (Kerr 1989). Order is not restored, comfort is not provided, and even the integrity of the detective is not fully intact. This defies the norms of the genre. Evans claims that "the narrative resolution offered by crime fiction comforts the reader, securing his/her worldview and ... provides a narrative escape from chaos and disorder" (Evans 1994), but the reader knows that in 1936 that the chaos and disorder was only just beginning. Ungar-Sargon, in a review of another popular Holocaust novel, warns that "the bugbear that aspiring Holocaust novelists should fear is not sensationalism, but the inherently tempting but ahistorical comforts of resolution." Kerr will not offer his reader any such comfort, nor will he even completely redeem his narrator-detective, thus forcing his readers to confront the inability of his form to provide any comfort in this particular setting. Moreover, the muteness of Gunther calls into question the ability of the detective narrator to articulate anything regarding the true horrors of the Holocaust.

Together with this juxtaposition between small-scale and large-scale crime, the very concept of crime is interrogated. In a criminal society, what meaning does crime have? When those who are purported to uphold law and order are themselves lawless and amoral, the very borders of civilized society are called into question. This dissolution of ordered society into chaos is highlighted at the end of The Pale Criminal. Having solved the mystery, and in the process uncovered dark and dirty secrets high up in the Nazi party of drug abuse, homosexuality, mental illness, and diabolic occult plans, Gunther confronts one of the primary murderers of seven young German girls. The murderer, who orchestrated the killings in order to frame a Jew for ritualistic murder and thus provoke a pogrom, nervously asks whether Gunther plans to murder him, to which Gunther replies, "In a civilized society you don't shoot a man in cold blood" (Kerr 1990). Having verbalized the rules of civilized society, Gunther considers the twisted and warped society in which he operates, and executes the perpetrator, shooting him in the head several times.

In a lawless and criminal society, where, on one hand, the murder of seven German girls, though a heinous crime, pales in comparison to the large scale crimes of calculated extermination being conducted by Nazi Germany, but, on the other hand, where justice is meted out in a vigilante fashion by state police, the borders between crime and justice are obscured, and Gunther's "grey idea of something you may as well call Morality" becomes even more grey and indistinct. Hall criticizes Kerr for stepping back as author at this point in the novel and not probing more deeply into the meaning of Gunther's actions as police, judge, and executioner. According to Hall, although "the execution of 
Kindermann ${ }^{7}$ can be viewed as either an act of perpetration (a Nazi policeman's abuse of power) or resistance (the elimination of a dangerous Nazi)—or even both simultaneously", Kerr does not make space for probing this question, and Gunther rushes on to the next step in closing his case. However, that night, Gunther's dreams present him with "beast men, preachers of death, scarlet judges and the outcasts of paradise" (Kerr 1990). It might be argued that Gunther's subconscious mind is condemning him for his actions, questioning whether he is a beast or man, a preacher of death, a judge with bloody hands, and as a result an "outcast of paradise" himself (Kerr 1990). Is Gunther himself the pale criminal of the novel's title?

\section{Undermining the Genre: The Detective Novel within the Detective Novel}

Having discussed the overlap and blurring of generic borders in this trilogy, the use of irony and metaphor and the flouting of the redemptive plot, I turn now to other ways in which Kerr subverts the genre. Here, his self-conscious mention of detective fiction within the novels is instructive. In March Violets, Gunther is summoned to meet Hermann Goering for the first time. Goering, "delighted at my being there", confesses, "I've always wanted to meet a real private detective" (Kerr 1989) and then goes on to ask whether Gunther has read any of Dashiel Hammett's detective stories. "He's an American", notes Goering, "but I think he's wonderful" (Kerr 1989). Hammett, described in his New York Times obituary as "the dean of the ... 'hard-boiled' school of detective fiction", "took murder out of the Venetian vase and dropped it into the alley" (Chandler 1972), creating the subgenre in a distinctly American style. Goering offers to lend Gunther a German edition of The Red Harvest, a hard-boiled novel in which the lines between heroes and villains are blurred, and moral ambiguity reigns. Ironically, Hammett would become a left-wing activist and join the Communist party, and in this way would have inspired Goering's derision and hatred. This is a joke on Goering, of course, one that adds to the character sketch provided by Gunther, "With his broad forehead, cold eyes, low growling voice, predatory grin and lazy belly, he reminded me of nothing so much as a big, fat, man-eating tiger" (1989). If Goering likes detective fiction, the reader might think, then we need to be sure not to be roped in by the seductions of stories, including the very detective story the readers are engaging with, and keep our eyes open to reality.

Later on in the book, Gunther meets Reinhard Heydrich, who, it turns out, also has "a passion for detective stories" (Kerr 1989), but after being on the receiving end of Gunther's irony and straight talk, remarks "The ability to talk as toughly as your fictional counterpart is one thing ... Being it is quite another" (Kerr 1989). Heydrich thus dismisses fiction and forces Gunther to confront real life- the mission to Dachau. When Gunther explores the consequences of refusing to work for Heydrich, Heydrich brightly informs him "You see, either way, you're going to Dachau. The difference is that working for me, you'll be sure to get out again" (Kerr 1989). Drawing a distinction between the fictional world of detective stories where the hard-boiled PI has choice and agency, in the new world orchestrated by Heydrich and the Nazi ilk, choice has become much more precarious. In fact, Kerr seems to be telling his readers to take fictional detective stories, including his, with a grain of salt, thus drawing attention in yet another way to the inadequacy of his form to properly represent the Nazi years.

\section{Conclusions}

Kerr's Berlin Noir trilogy falls squarely into the category of popular crime fiction, with its attendant murders, mysteries and detectives, and the expectation of a pleasure-inducing read. However, set as it is in Nazi Germany, the trilogy cannot play out as a mere detective novel if it is to ethically represent the realities of Nazi Germany. Thus, Kerr undermines his own genre, even at the price of failing to

7 Kindermann is the main perpetrator of the plot to murder the German girls and provoke a pogrom by blaming the murder on the Jews. 
provide the binarism and closure that pleases readers of popular crime fiction. Nazi Germany is much more than the mere setting of these novels. In fact, sometimes the small-scale crime, ostensibly the focus of the novels, is eclipsed by the representation of the Nazi regime and its large-scale crimes. This representation brings on a crisis of genre in the novels, a situation where the sub-genres blur into each other and overlap. This slippage, together with the tropes of irony, metaphor, and metafictional critique, cause discomfort in the reader, a discomfort that is fitting to any responsible depiction of the horrors unleashed by Nazi Germany. The trilogy does not face the Holocaust directly, only offering glimpses from Gunther's limited viewpoint, but even this limited view is undermined and called into question by the protagonist's precarious position between hard-boiled detective and Nazi policeman. Kerr, perhaps most significantly, refuses to give his readers resolution and closure. Instead, all we have is a morally ambiguous hero, "just a weather-beaten man in a crumpled overcoat on a street corner" (Kerr 1990), doing his best to resist the new reality, even just internally. His "grey idea of something you might as well go ahead and call Morality" is perhaps the most the reader can expect in the world of Belin noir.

Funding: This research received no funding.

Conflicts of Interest: The author declares no conflict of interest.

\section{References}

Aarons, Victoria. 2014. A genre of rupture: The literary language of the Holocaust. In The Bloomsbury Companion to Holocaust Literature. Edited by Jenni Adams. London and New York: Bloomsbury Academic, pp. 27-46.

Adorno, Theodor W. 1986. "Cultural Criticism and Society," in Prisms, Trans. Samuel and Shierry Weber. Cambridge: MIT Press.

Auden, Wystan Hugh. 1948. The guilty vicarage: notes on the detective story, by an addict. Harper's Magazine. Available online: https://harpers.org/archive/1948/05/the-guilty-vicarage (accessed on 12 August 2019).

Auden, Wystan Hugh, and Louis MacNeice. 2018. "Detective Story" Letters from Iceland. London: Faber \& Faber. First published in 1936.

Chandler, Raymond. 1972. The Simple Art of Murder. In The Simple Art of Murder. New York: Ballantine, pp. 16-17.

Diemert, Brian. 2002. How Do You Describe the Indescribable? Representing History in Detective Fiction: The Case of Philip Kerr's Berlin Noir Trilogy. Genre 35: 331-53. [CrossRef]

Donahue, William Collins. 2004. The Popular Culture Alibi: Bernhard Schlink's Detective Novels and the Culture of Politically Correct Holocaust Literature. The German Quarterly 77: 462-81. Available online: http://www.jstor.org/stable/4488705 (accessed on 26 August 2019).

Evans, Christine Ann. 1994. On the Valuation of Detective Fiction: A Study in the Ethics of Consolation. Journal of Popular Culture 28: 159-67. [CrossRef]

Grella, George. 1980. The hard-boiled detective novel. In Detective Fiction: A Collection of Critical Essays. Edited by Robin W. Winks. Englewood Cliffs: Prentice, pp. 103-20.

Hall, Katharina. 2013. The "Nazi Detective" as Provider of Justice in Post-1990 British and German Crime Fiction: Philip Kerr's The Pale Criminal, Robert Harris's Fatherland, and Richard Birkefeld and Göran Hachmeister's Wer übrig Bleibt, Hat Recht. Comparative Literature Studies 50: 288-313. [CrossRef]

Hartman, Geoffrey, ed. 1994. Holocaust Remembrance: The Shapes of Memory. Oxford: Blackwell.

Kerr, Philip. 1989. March Violets. In Berlin Noir. London: Penguin.

Kerr, Philip. 1990. The Pale Criminal. In Berlin Noir. London: Penguin.

Kerr, Philip. 1991. A German Requiem. In Berlin Noir. London: Penguin.

Kniesche, Thomas W. 2013. Weimar and Nazi Germany in Contemporary German Historical Crime Fiction. Colloquia Germanica 46: 116-30.

Lake, Anthony. 2016. But What's One More Murder?" Confronting the Holocaust in Philip Kerr's Bernie Gunther Novels. ATLANTIS Journal of the Spanish Association of Anglo-American Studies 38: 89-107.

Lang, Berel. 2000. Holocaust Representation: Art within the Limits of History and Ethics. Baltimore: JHU Press. 
Langer, Lawrence. 1980. The Dilemma of Choice in the Deathcamps. Centerpoint: A Journal of Interdisciplinary Studies 4: 53-58.

Langer, Lawrence, ed. 1995. Art from the Ashes: a Holocaust Anthology. New York: Oxford University Press.

Lanzmann, Claude. 1994. Why Spielberg Has Distorted the Truth. Guardian Weekly 3: 14.

Malmgren, Carl D. 1997. Anatomy of Murder: Mystery, Detective, and Crime Fiction. Journal of Popular Culture 30: 115-35. [CrossRef]

Most, Glenn W. 1983. The Hippocratic smile: John Le Carré and the traditions of the detective novel. In The Poetics of Murder: Detective Fiction and Literary Theory. Edited by GW Most and William W. Stowe. San Diego: Harcourt Brace Jovanovich, pp. 341-65.

Reichek, Morton A. 1976. Elie Wiesel: Out of the Night. In Present Tense: The Magazine of World Jewish Affairs. New York: The American Jewish Committee.

Rzepka, Charles J., and Lee Horsley. 2010. A Companion to Crime Fiction. Chichester: Wiley-Blackwell. Vice, Sue. 2000. Holocaust Fiction. New York: Routledge.

Wilson, Edmund. 1945. Who cares who killed Roger Ackroyd? In The Art of the Mystery Story: A Collection of Critical Essays. Edited by Howard Haycraft. New York: Simon \& Schuster, pp. 390-97.

(C) 2019 by the author. Licensee MDPI, Basel, Switzerland. This article is an open access article distributed under the terms and conditions of the Creative Commons Attribution (CC BY) license (http://creativecommons.org/licenses/by/4.0/). 